\title{
To Quote or not to Quote: Citation Strategies in the Encyclopédie
}

\section{Dan Edelstein, Robert Morrissey, and Glenn Roe}

Ever since the first volume of the Encyclopédie was published in 1751, critics have complained about its liberal, and often unacknowledged, borrowings from other sources. ${ }^{1}$ The impression that this work, often hailed as the masterpiece of the Enlightenment, was merely cobbled together from bits and pieces of other books was reinforced by the composition method of the most prolific contributor, the Chevalier de Jaucourt, who was known to employ a handful of secretaries, each of whom took dictation as the chevalier read from different texts. ${ }^{2}$

Research for this paper was made possible by an National Endowment for the Humanities (NEH) grant (RF 50003-09) for a fellowship at a digital humanities center, namely the ARTFL project at the University of Chicago. The authors would also like to thank Mark Olsen, Nicholas Cronk, Tim Allen, Clovis Gladstone, and Joseph St-Meyer.

${ }^{1}$ Encyclopédie, ou dictionnaire raisonné des sciences, des arts et des métiers (Paris: 175172). See the criticism of the Père Berthier, Journal de Trévoux (October 1751). On the Encyclopédie's use of other dictionaries, see Marie Leca-Tsiomis, Écrire l'Encyclopédie': Diderot: de l'usage des dictionnaires à la grammaire philosophique (Oxford: Voltaire Foundation, 1999). On plagiarism in the early modern period, see notably Marilyn Randall, Pragmatic Plagiarism: Authorship, Profit, and Power (Toronto: University of Toronto Press, 2001), and Borrowed Feathers: Plagiarism and the Limits of Imitation in Early Modern Europe, ed. Hall Bjornstad (Oslo: Unipub, 2008). On the Encyclopédie more generally, see Jacques Proust, Diderot et l'Encyclopédie' (Paris: A. Michel, 1995); John Lough, Essays on the 'Encyclopédie' of Diderot and d'Alembert (Oxford: Oxford University Press, 1968); and Robert Darnton, The Business of Enlightenment: A Publishing History of the Encyclopédie, 1775-1800 (Cambridge, Mass.: Harvard University Press, 1979).

2 On Jaucourt, see Madeleine Morris, Le chevalier de Jaucourt, un ami de la terre (Geneva: Droz, 1979). On the encyclopédistes in general, see Frank Kafker, The Encyclo- 
This line of criticism was in fact undercut by the editors of the Encyclopédie in their "Avertissement" to the third volume. Collecting the best parts of other works was precisely one of their goals, they countered: their articles were intended to help modern readers avoid "information overload," and to lead them straight to the most salient and important sections of past authors. ${ }^{3}$ In this regard, as Richard Yeo and Ann Blair, among others, have noted, the Encyclopédie may be seen as a late bookend for the early-modern tradition of commonplace books. ${ }^{4}$

Even after this genealogy has been identified, however, we are left with the same question as before: why not cite? Most articles in the Encyclopédie, after all, are crammed with learned references; the editors, moreover, insisted that this was the scholarly practice they wished to see respected in their articles. ${ }^{5}$ Few authors in the eighteenth century, of course, adhered to today's professional norms of citation, yet the encyclopédistes could be quite exact, indicating not only name and title of cited work, but also chapter, section, and page number. But they did not always live up to this standard of modern citation. ${ }^{6}$

This article explores some of the reasons why not citing may have been an important publishing and philosophical strategy. Using a data-mining program that automatically flags likely matches between texts, we were able to identify thousands of citations, both acknowledged and unacknowledged, and to discover clear citational patterns. ${ }^{7}$ Taking into account the complicated system of publishing permissions in Old Regime France, we show that many instances of non-citation occurred for books that were published anonymously and/or without a royal privilège. ${ }^{8}$ Accordingly, we

pedists as a Group: A Collective Biography of the Authors of the Encyclopédie (Oxford: Voltaire Foundation, 1996).

3 "Avertissement," Encyclopédie, 3: vii. See the special issue on "Early-Modern Information Overload," ed. Daniel Rosenberg, Journal of the History of Ideas 64 (2003): 1-134; and Ann Blair, Too Much To Know: Managing Scholarly Information Before the Modern Age (New Haven: Yale University Press, 2010).

${ }^{4}$ Richard Yeo, Encyclopedic Visions: Scientific Dictionaries and Enlightenment Culture (Cambridge: Cambridge University Press, 2001); and Ann Blair, Too Much to Know.

5 "Avertissement," vol. 3. On the history of citation, see notably Carlo Ginzburg, Threads and Traces: True False Fictive, trans. Anne C. and John Tedeschi (Berkeley: University of California Press, 2012), chap. 1.

${ }^{6}$ For a comprehensive treatment of early modern citational practices, see Anthony Grafton, The Footnote: A Curious History (London: Faber \& Faber, 2003).

${ }^{7}$ This process is discussed more fully in the section on methodology below. Readers can explore this method on their own, and check our results, using the search form available online: http://artfl-project.uchicago.edu/content/encyclopédie.

${ }^{8}$ On the censorship system in eighteenth-century France, see notably Raymond Birn, $\mathrm{La}$ censure royale des livres dans la France des Lumières (Paris: Odile Jacob, 2007); and 
argue that there was a "subversive style" of non-citation: by not identifying their references, contributors were able to incorporate into the Encyclopédie extensive passages of banned or forbidden books.

In other cases, however, the absence of attribution does not seem related to the subversive nature of texts, but rather to the desire to appeal to a wider audience by avoiding the appearance of pedantry. ${ }^{9}$ We propose calling this the "worldly style" of non-citation, as opposed to what might be termed the "learned style," in which references are systematically produced. Interestingly, both of these styles are present in the Encyclopédie-an indication, perhaps, of this work's transitional status, halfway between early modern humanist practices and modern reference works. In other respects, however, techniques related to the older genre of commonplace books foreshadow the indexing and retrieval functionality of online search engines, an analogy that perhaps sheds new light on the compilation process of the Encyclopédie. Finally, having uncovered a vast body of unacknowledged citations, we are better placed to evaluate the overall tenor and intellectual thrust of the Encyclopédie. Contrary to the recent claim that this work was steeped in "Spinozist" philosophy, we demonstrate that it was overwhelmingly tilted toward such authors as Voltaire and Montesquieu. ${ }^{10}$

\section{METHODOLOGY}

The source texts we compared with the Encyclopédie were all examined using a sequence alignment program called PhiloLine, an open source data mining extension to the ARTFL Project's PhiloLogic search engine. ${ }^{11}$ Borrowing techniques first developed in the field of bioinformatics for DNA sequencing, PhiloLine's sequence alignment algorithms work by treating

T.C.W. Blanning, The Culture of Power and the Power of Culture: Old Regime Europe, 1660-1789 (Oxford: Oxford University Press, 2002).

${ }^{9}$ On the fear of pedantry, see notably Jean Seznec, "Le singe antique," in Essais sur Diderot et l'Antiquité (Oxford: Clarendon Press, 1957), 79-96; Henri Gouhier, L'antihumanisme au XVII e siècle (Paris: Vrin, 1987); Blandine Barret-Kriegel, La défaite de l'érudition (Paris: Presses Universitaires de France, 1988); and Chantal Grell, L'histoire entre érudition et philosophie: étude sur la connaissance historique à l'âge des Lumières (Paris: Presses Universitaires de France, 1993).

${ }^{10}$ See Jonathan Israel, Enlightenment Contested: Philosophy, Modernity, and the Emancipation of Man, 1670-1752 (Oxford: Oxford University Press, 2006).

${ }^{11}$ On the PhiloLogic search engine, see: https://sites.google.com/site/philologic3/; the PhiloLine code base can be found here: http://code.google.com/p/text-pair/. 
documents as ordered sets of $n$-grams, or groups of $n$ number of content words taken from a given sequence or collection. (These are the same $n$-grams, coincidentally, that have recently gained in notoriety thanks to the ground-breaking work on "culturomics" by Erez Lieberman Aiden and J.-B. Michel, and the subsequent Google Books N-Gram Viewer visualization tool. ${ }^{12}$ ) For our purposes, we set out to identify ordered sets of $n$-grams, or what are called "shingles." Shingles are formed by overlapping sequences of $n$ words in a given document.

Before any cross-collection comparison could be performed, however, we had to pre-process the data from the Encyclopédie and our target sources, removing many overly common function words and reducing the number of orthographic variants. This step in the process effectively folds numerous shingles into one underlying form for matching purposes, thus eliminating minor textual variations, and making our matching algorithm much more flexible and robust; a flexibility that is essential given the "noisy" information space of humanities text collections. Rousseau's famous incipit from the Contrat social can perhaps provide a more visual example of the process, wherein:

L'homme est né libre, et partout il est dans les fers. Tel se croit le maître des autres, qui ne laisse pas d'étre plus esclave qu'eux.

rendered as trigrams ( $n$-grams with $n=3$ ), with short and function words removed and accents and case flattened, would look like:

$\begin{array}{llll}\text { trigram } & \text { doc } & \text { sequence } & \text { bytes } \\ \text { homme_libre_partout } & 755 & 208-213 & 5084-31 \\ \text { libre_partout_fers } & 755 & 211-218 & 5098-38 \\ \text { partout_fers_croit } & 755 & 213-221 & 5108-46 \\ \text { fers_croit_maitre } & 755 & 218-223 & 5132-33 \\ \text { croit_maitre_laisse } & 755 & 221-228 & 5149-42 \\ \text { maitre_laisse_esclave } & 755 & 223-233 & 5158-58\end{array}$

The shingles are indexed with a document identifier, word sequence range, and the source file byte position and size of the corresponding section of the text. An ordered list of shingles is generated for each document in the

\footnotetext{
${ }^{12}$ See Jean-Baptiste Michel, et al., "Quantitative Analysis of Culture Using Millions of Digitized Books," Science (December 16, 2010): 1199644. The Google Books N-Gram Viewer can be found here: http://ngrams.googlelabs.com/.
} 
comparison task. Each shingle also becomes a key in an index of all shingle occurrences for the entire collection of documents, so that all occurrences of a given shingle can be readily retrieved.

The first step in identifying shared text sequences between source documents and the Encyclopédie entailed finding these shared shingles of $n$-grams. We then defined several of the matching criteria such as minimum overlap of shingles between two sets, minimum length of a shared shingle sequence, and the maximum number of consecutive gaps allowed between matching sequences in either set. This last parameter is important as it allows us to find matches with significant variations in orthography and even word order. For example, we were able to identify the following passage from a 1783 edition of David Mazel's French translation of Locke's Second Treatise found in the Gale-ECCO database:

limité; quand ce tems-là est fini,. le pouvoir souverain retourne à la société; \& quand il y ef retourné de cette manière, la société en peut disposer comme il lui plaît, $\&$ le remettre entre les mains de ceux qu'elle trouve bon, \& ainfi établir une nouvelle forme de gouvernement. ${ }^{13}$

Recycled in the Encyclopédie article "Governement" (v. 7, p. 789), note the textual variations in bold:

limité, quand ce tems-là est fini, le pouvoir souverain retourne à la société dont il émane. Dès qu'il y est retourné, la societé en peut de nouveau disposer comme il lui plait, le remettre entre les mains de ceux qu'elle trouve bon, de la maniere qu'elle juge à-p ropos, \& ainsi ériger une nouvelle forme de gouvernement.

In this particular case, although the 1783 translation is posterior to the Encyclopédie's publication and the match is far from exact, we were still able to identify that the Chevalier de Jaucourt, author of the article in question, was drawing directly on Locke's Treatise. Most likely, Jaucourt was using a contemporary variation of Mazel's 1691 translation. ${ }^{14}$ But, regardless of the exact translation Jaucourt may have used, it is nonetheless cer-

${ }^{13}$ Du gouvernement civil, par M. Locke, traduit de l'anglois ... (London [Paris?], 1783), 205.

${ }^{14}$ See S.-J. Savonius, "Locke in French: The Du Gouvernement Civil of 1691 and Its Readers," The Historical Journal 47 (2004): 47-79. 
tain that Locke's treatise formed the primary source material for his article, whether drawn from a somewhat different translation not included in any of the corpora available to us, or slightly adapted by Jaucourt himself to suit his needs.

The flexible matching criteria outlined above are thus essential for finding these types of non-exact matches between the Encyclopédie and its possible sources. And, given that most humanities text databases are based on uncorrected OCR (optical character recognition) procedures, the ability to find related passages with a high degree of variability is of the utmost importance. In comparing the Encyclopédie with our various collected sources, we evaluated the above parameters for each document and, where the threshold criteria were met, a match was expanded, examining wider contexts in each document. Once the criteria were violated and the matching sequences diverged, the passages in question were recorded.

The corpus that we assembled for this project was rather heterodox and certainly far from exhaustive. Our point of departure was the FRANTEXT database run by the ARTFL project. ${ }^{15}$ This database contains over 2,900 French language texts from a variety of disciplines-literature, philosophy, political thought, history, etc.- - ranging from the twelfth century to the twentieth century. All of the texts were digitized by a double-key data entry procedure, which guarantees $99.95 \%$ word accuracy. For our experiment, we ran the sequence aligner on the roughly 900 titles published before 1765 . This yielded a total of 5,763 results, where each result represents a match between a passage of the Encyclopédie and a passage in a source text.

We also ran the sequence aligner on works written in, or translated into, French, and published before 1765, contained in the Eighteenth Century Collections Online (ECCO) database. ${ }^{16}$ This selection represents 1,658 titles and allowed us to capture French translations of such authors as Bolingbroke, David Hume, John Locke, and Alexander Pope. As with Google Books, ECCO was produced by scanning books and digitizing their contents with OCR. Since this output was not corrected, it is often described as "dirty OCR" and has a much lower accuracy rate. In practical terms, this means that the sequence aligner is liable to miss more matches. Still, thanks to the flexible matching criteria, and in particular the maximum gap parameter, we were able to find a high number of matches in the dirty OCR

\footnotetext{
${ }^{15}$ See http://artfl-project.uchicago.edu/node/23 (subscription required).

${ }^{16}$ See http://galenet.galegroup.com/servlet/ECCO (subscription required).
} 
as well. Finally, we also selected French texts published between 1527 and 1720 from the "Making of the Modern World" (MOME) database. ${ }^{17}$ This selection encompassed 1,359 titles, and yielded 4,393 results. MOME was produced by digitizing the Goldsmiths'-Kress microfilm collection and also consists of uncorrected OCR output.

Despite the limitations of digital sources that contain numerous spelling errors, the sequence alignment procedure still produced more results than we could process. Because each result must be analyzed individually in a labor-intensive manner, described in the following section, and because the results also include a fair amount of "noise," e.g., passages that quote the same Latin expression, or provide the same list of monarchs, the overall statistical results are not very telling. We therefore had to select which authors and works we thought would yield the most valuable insights. Accordingly, we focused primarily on three groups of authors: major Enlightenment authors, including Voltaire and Montesquieu; canonical French authors, from Montaigne to Bossuet; and what might be considered controversial or subversive authors, such as Locke, Hume, and Helvétius.

The above methodological description requires two caveats. First, we should acknowledge an important source that this study does not encompass: dictionaries. It has been estimated that a little more than $5 \%$ of the Encyclopédie's articles are borrowed almost directly from the Jesuit Dictionnaire de Trévoux ${ }^{18}$; no doubt a similar amount of text was taken from the Chambers's Cyclopedia and from the Dictionnaire de commerce, both of which figure among the top thirty most cited authorities in the Encyclopédie. ${ }^{19}$ But borrowing copy from other dictionaries was a common trick of all encyclopedic and dictionary endeavors. Diderot and d'Alembert admitted as much in their response to the Père Berthier ("Avertissement des éditeurs," vol. 3 of the Encyclopédie), pointing out that the Dictionnaire de Trévoux, itself based on the seventeenth-century Dictionaire universel of Antoine Furetière, was equally guilty of this sin. This sort of borrowing necessarily falls into a different category, therefore, than copying passages out of other books.

\footnotetext{
${ }^{17}$ See http://galenet.galegroup.com/servlet/MOME (subscription required).

${ }^{18}$ See Timothy Allen et al., "Plundering Philosophers: Identifying Sources of the Encyclopédie," Journal of the Association for History and Computing 13 (2010): http://quod.lib.umich.edu/j/jahc/ .

${ }^{19}$ See Dan Edelstein, "Humanism, l'Esprit Philosophique, and the Encyclopédie," Republics of Letters 1 (2009): http://rofl.stanford.edu/node/27.
} 


\section{ORDERING CITATIONS}

The challenge we faced in making sense of the citational practices in the Encyclopédie can be illustrated by the following example. The article "Liberté," attributed to Naigeon and the Abbé Yvon, contains two clearly identified citations from Leibniz, but also two unacknowledged citations of the same author that are simply woven into the text. ${ }^{20}$ These silent quotes do not seem qualitatively much different from the passages that are placed in quotation marks. At first glance, the authors simply appear to be inconsistent and undoubtedly there is a degree of inconsistency in the stylistic choices of the contributors: their large number, the lack of significant editorial oversight, and a frantic production pace are in themselves a recipe for variability. As we hope to demonstrate, however, there is also some method to this apparent madness.

A first point to recognize is that not all primary sources are equal. Their differences can be measured in a variety of ways, but one important distinction between them concerns their publication status. Indeed, in Old Regime France, books published with a royal privilège occupied a completely different niche, both literally and intellectually, than books that circulated clandestinely through the country. ${ }^{21}$ Authors had at their disposal a whole range of publication strategies: they could petition government censors for a permission tacite, which ensured that authorities would turn a blind eye on the distribution of their book; they could publish anonymously, pseudonymously, or under their given name, abroad or clandestinely; or they might even choose to circulate their works in manuscript form (see Table 1). Given the legal implications of this system, one would expect authors citing other works to take into account their official or banned status. It was a very different matter, for instance, to cite Voltaire's Henriade—originally published in 1728 without a privilège in London, and soon thereafter in The Hague, but available in France with a permission tacite after 1730-than to cite his Lettres philosophiques, which had been

\footnotetext{
${ }^{20}$ See "Liberté," Encyclopédie, 9: 471, as well as the final three sentences of the article. Compare with Leibniz's Essais de théodicée: sur la bonté de Dieu, la liberté de l'homme et l'origine du mal (1710; Paris: Aubier, 1962), 302 [FRANTEXT]. The two explicit quotations from Leibniz in the "Liberté" article are from this same text.

${ }^{21}$ See notably Robert Darnton, The Forbidden Best-Sellers of Pre-revolutionary France (New York: Norton, 1996); Birn, La censure royale des livres; and Daniel Roche, "Censorship and the Publishing Industry," in Revolution in Print: The Press in France, 17751800, ed. Robert Darnton and Daniel Roche (Berkeley: University of California Press, 1989), 3-26.
} 
condemned to be burned by the Parlement de Paris in $1734 .^{22}$ As we will see, differences in publication status account to a considerable degree for variations in citation strategies.

Table 1: Publication Status

1. Manuscript anonymity.

2. Anonymous, unauthorized publication.

3. "Falsely anonymous," unauthorized publication.

4. Pseudonymous, unauthorized publication (Voltaire's preferred strategy).

5. Collective anonymity, authorized publication (e.g., encyclopedia art.).

6. Signed, unauthorized (e.g. Rousseau's Emile; translations of Locke).

7. Signed, published with a permission tacite.

8. Signed, published with royal privilège.

When examining individual citations, secondly, we must also recognize that attribution is not an easily settled question. To be sure, there are extreme cases, ranging, on the one hand, from the meticulous identification of quotes all the way down to chapter and verse, to, on the other hand, the complete effacement of an original source. But a host of other possibilities exists in between. The "Liberté" example with which we started is in fact very typical: often contributors will explicitly cite an author in one place, but then include other unattributed passages by the same author elsewhere in the article. Hence, in "Géographie," for instance, Didier Robert de Vaugondy directly quotes Buffon's Histoire naturelle in one paragraph, but then inserts another long Buffon passage without attribution, or even quotation marks, a few pages later. ${ }^{23}$ Another common method of indicating a source is to reference an author, or a work, at the beginning or end of the article: numerous articles with Montesquieu quotes stuffed in them end simply with "Voyez l'Esprit des lois." Sometimes passages are marked as quotes, but their sources are not clearly identified: for instance, when Jaucourt cites Helvétius's De l'esprit, a book published in 1758 with a privilège $d u$ roi, that was swiftly revoked, but condemned to be burned by the Paris Parlement, he merely refers to "un beau genie de ce siècle" (see "Lacédemone"). Other passages are falsely attributed: in this same article, "Lacédemone," Jaucourt attributes to Plutarch a passage that he in fact borrows

\footnotetext{
${ }^{22}$ On the Henriade's publication history, see notably Georges Bengesco, Voltaire: bibliographie de ses ceuvres, 4 vols. (Paris: Emile Perrin, 1882-85), 1: 104.

${ }^{23}$ In the paragraph beginning "Phénomenes qui indiquent...." (Encyclopédie, 7: 623).
} 
from Helvétius. ${ }^{24}$ Finally, quotes can be attributed to an author without referencing a title ("comme dit M. de Montesquieu ..."), or a contrario only by title ("dit l'auteur de l'Esprit des lois"). This range of possibilities is expressed in the following table:

\section{Table 2: Typology of Citation}

1. No citation whatsoever in article (for author in question)

2. None for citation, but citations by other authors identified in article.

3. Acknowledged, but unattributed (e.g., "un esprit de nos temps").

4. Citation not identified, but reference included at the beginning/end of article.

4.5 Citation not identified, but book title mentioned in text.

5. Citation not identified, but author's name mentioned in text.

5.5 Entire article presented as the summary of another work.

6. Attributed by periphrase (e.g., "l'auteur de l'Henriade").

7. Attributed by name (e.g., "comme dit M. de Montesquieu ....").

7.5 Attributed by title.

8. Attributed by author's name and book title.

9. Attributed by name, title, and page/section.

10. Misattributed (to a different author).

Scoring every citation in this manner is very time consuming, as it requires the assessor to read the full article, in order to determine whether a reference to the work or author cited can be found in some part, and in some form, of the text. Some categories, we decided, were not particularly interesting (such as category number 2). We also added categories along the way, which explains the use of integers, required to maintain a certain gradation. In the end, however, this rather complicated breakdown, which is certainly not exhaustive, can be summarized by four principal categories:

\section{Table 3: Typology of Citation, General}

1. No attribution.

2. Indirect attribution (some mention of author or text in article).

3. Direct attribution (passage is clearly linked to an author or text).

4. Precise attribution (passage is clearly linked to author and text).

The advantage of this general gradation is that it allows us to "score" different works fairly easily. For example, we identified and categorized the

24 “Lacédemone," Encyclopédie, 9: 155. This anecdote may possibly be traced back to Plutarch, though we could not locate it, but the wording matches Helvétius's text exactly. 
547 quotes from Montesquieu's De l'esprit des lois that we found in the Encyclopédie: 89 of these (16\%) appear without any attribution whatsoever; for 199 others (36\%), there was some degree of attribution, i.e., indirect; 233 quotes (43\%) were clearly attributed; and another 26 (5\%) were identified "precisely." 25 The average "attribution score" for De l'esprit des lois thus turns out to be 4.7 (out of 8 ). ${ }^{26}$ The following table provides a sample of the works we examined and scored in this fashion:

\section{Table 4. Works Cited in Encyclopédie (selection), Scored for Average} Attribution of Citations

\begin{tabular}{|c|c|c|c|c|}
\hline Author & Title & Total \# & $\begin{array}{l}\text { Attribution } \\
\text { score }\end{array}$ & $\begin{array}{c}\text { Publication } \\
\text { status }\end{array}$ \\
\hline Barbeyrac & $\begin{array}{l}\text { Les devoirs de l'homme; } \\
\text { Le droit de la nature et } \\
\text { des gens }\end{array}$ & 38 & 3.6 & 6 \\
\hline Bolingbroke & $\begin{array}{l}\text { Lettres sur l'esprit de } \\
\text { patriotisme, sur l'idée }\end{array}$ & & & \\
\hline & d'un roy patriote & 18 & 2 & 2 \\
\hline Bossuet & $\begin{array}{l}\text { Discours sur l'histoire } \\
\text { universelle }\end{array}$ & 15 & 4 & 8 \\
\hline Bossuet & $\begin{array}{l}\text { Oraison funebre d'Hen- } \\
\text { riette d'Angleterre }\end{array}$ & 3 & 8 & 8 \\
\hline Buffon & $\begin{array}{l}\text { Histoire et théorie de la } \\
\text { terre; Histoire naturelle, } \\
\text { premier discours; L'Ane }\end{array}$ & 12 & 6.3 & 8 \\
\hline Condillac & $\begin{array}{l}\text { Essai sur l'origine des } \\
\text { connaissances humaines }\end{array}$ & 102 & 3.4 & 2 \\
\hline Diderot & Pensées philosophiques & 4 & 3.5 & 2 \\
\hline Diderot & $\begin{array}{l}\text { Essai sur le mérite et la } \\
\text { vertu de Shaftesbury }\end{array}$ & 6 & 4.3 & 2 \\
\hline Dubos & $\begin{array}{l}\text { Réflexions critiques sur } \\
\text { la poésie... }\end{array}$ & 279 & 3.8 & 8 \\
\hline Duclos & $\begin{array}{l}\text { Considérations sur les } \\
\text { mœurs }^{27}\end{array}$ & 19 & 4.8 & 7 \\
\hline \multicolumn{5}{|c|}{$\begin{array}{l}{ }^{25} \text { We owe a special thanks to Joseph St-Meyer for analyzing the Montesquieu results. } \\
{ }^{26} \text { Since our "publication status" table ranges from } 1 \text { to } 8 \text {, we doubled, for the sake of } \\
\text { simplicity, the value of each kind of attribution: i.e., no attribution = a score of } 2 \text {, indi- } \\
\text { rect attribution = a score of } 4 \text {, etc. } \\
{ }^{27} \text { Duclos's work was granted a permission tacite in 1751: see the BnF notice } \\
\text { FRBNF30365519. Duclos was a member of the French Academy, and intellectually } \\
\text { aligned with the philosophes. }\end{array}$} \\
\hline
\end{tabular}


Table 4. (Continued)

\begin{tabular}{llccc}
\hline Author & Title & Total \# & $\begin{array}{c}\text { Attribution } \\
\text { score }\end{array}$ & $\begin{array}{c}\text { Publication } \\
\text { status }\end{array}$ \\
\hline Duclos & Histoire de Louis XI & 8 & 3.75 & 8 \\
Helvétius & De l'esprit & 12 & 3.2 & 6 \\
Hume & Discours politiques. . . & 15 & 2.5 & 7 \\
Leibniz & Essais de théodicée & 30 & 4.6 & 6 \\
Locke & Du gouvernement civil & 34 & 2 & 6 \\
Locke & Abregé de l'essay sur & & & \\
& l'entendement humain & 10 & 4 & 6 \\
Locke & De l'éducation des & & & 6 \\
& enfans & 2 & 6 & \\
Montaigne & Essais & 55 & 4.7 & 4 \\
Montes- & De l'esprit des lois & & & 6 \\
quieu & & 547 & 4.7 & 2 \\
Voltaire & Lettres philosophiques & 32 & 3.8 & 6 \\
Voltaire & Le Siècle de Louis XIV & 80 & 4.5 & \\
Voltaire & La Henriade & 23 & 6.1 &
\end{tabular}

What do these numbers tell us? In many cases, they confirm our initial hypothesis: works that score high on publication status, i.e., that are openly authored and benefit from official protection, tend to have a much higher attribution score, i.e., they will be cited with direct or precise attribution. At upper end of the spectrum, for instance, we find Buffon (attribution score $=6.3$ ), whose works were all published with a royal privilège ${ }^{31}$ and the bottom end lies Bolingbroke, whose Lettres (attribution score $=2$ ), including the "Idée d'un roi patriote" and "Lettre première sur l'esprit de patriotisme," were translated and published anonymously (in 1750), abroad, without official approval. ${ }^{32}$ None of the 18 quotations we identified from this source were attributed.

${ }^{28}$ The 1745 edition, published by Guérin in Paris, was granted a royal privilege.

${ }^{29}$ This edition is a translation of Hume's Essays and Treatises on Several Subjects, 2nd ed. (Edinburgh: Kincaid, 1753), vol. 4. A number of French editions appeared in 1754, one of which, published by Michel Lambert in Paris, with a false Amsterdam address, was granted a permission tacite (see BnF notice FRBNF30628431).

${ }^{30}$ With the exception of two, probably unauthorized, 1752 editions, most editions of this work were published anonymously, as per Voltaire's instructions, without a privilège or permission tacite. See Bengesco, Voltaire, 2: 340-52.

${ }^{31}$ In the cases of Buffon and Barbeyrac, we made an exception and did not distinguish between individual works, as they were all of a similar genre, and shared the same publications status.

${ }^{32}$ This was a translation of Bolingbroke's Letters, on the Spirit of Patriotism; on the Idea 


\section{THE ART OF NON-CITATION}

This trend is fairly commonsensical, but underscores an important strategy employed by the contributors to the Encyclopédie. Works that could be considered dangerous-both because of their publication status, but also because of their content-tended to be cited without attribution. The subversive inclusion of Bolingbroke is emblematic of how most translations from English were used. Not a single one of the 38 passages borrowed from the French translation of Locke's second Treatise is attributed, or even, for that matter, acknowledged as quotation. Hume fares only slightly better: his Discours politiques, which were first translated in 1754, are cited 15 times, but only attributed to the author twice.

Given that these were political works that occasionally challenged the very foundations of the French monarchy, smuggling them into a text that was published with a royal privilège, subsequently replaced by a permission tacite, appears as a wily publishing strategy. That this was a strategic move and not simply laziness or guile is evident from the very different treatment granted to, say, Locke's much less radical Essay Concerning Human Understanding (attribution score $=4$ ), which is quoted with attribution roughly two-thirds of the time. All of these instances involve Jaucourt. Conversely, other forbidden texts, written in French, receive the same treatment as the English political works: Helvétius's 1758 De l'esprit is cited 14 times, but never directly or precisely attributed (score $=3.2$ ). As we saw, this book had attracted the fury of the Parisian Parlement, and would ultimately be indirectly responsible for the 1759 condemnation and momentary closure of the Encyclopédie project. ${ }^{33}$

These data are admittedly small, and may not be fully representative. Yet it is also worth considering how the articles in which these "smuggled" quotes feature regularly attribute other quotes to their respective authors. In his article on "Primogéniture," for instance, Jaucourt refers the reader to Budé's (Johann Franz Buddeus) De successione primogenitorum, but doesn't mention the Hume essay from which he quotes, "Of the Populousness of Antient Nations." Similarly, in the article "Vice," the quotes from Racine and Montaigne are both acknowledged and properly attributed, whereas the quote from Bolingbroke's "Idea of a Patriot King" is not. The contributors clearly knew when not quoting was in their best interest.

of a Patriot King; and On the State of Parties, At the Accession of King George the First (London: Millar, 1749).

${ }^{33}$ See Blanning, The Culture of Power, 378-81. 
The strategic attempt to elude censors can also be seen in another technique, namely misattribution. The article "Téléologie," also by Jaucourt, informs the reader that it presents "les réflexions suivantes du chancelier Bacon," whereas in fact the last paragraph, which criticizes monarchs who believe themselves to be "the final cause for which all societies have been formed" 34 is taken from Bolingbroke's "Idea of a Patriot King." The latter author, however, is much more "suspicious" than the former, a canonized authority. Jaucourt resorts to a similar trick in the article "Courage," where he attributes to Tacitus a statement about tyranny, which in fact comes from Charles Duclos's Considérations sur les mours de ce siècle (1751). Of course, it is always possible that Jaucourt was simply confusing his sources; yet he clearly felt less comfortable citing Duclos as an authority, since later in the article he only alludes to him indirectly as "un auteur moderne." It was certainly safer to cite un auteur ancien, especially Tacitus, rather than a moderne when dealing with the touchy subject of tyranny.

Because the publication of the Encyclopédie text volumes stretched out over fifteen years, from 1751 to 1765 , we can also track the evolution of "subversive" works over time. As mentioned earlier, Voltaire's Lettres philosophiques is the prime example of a book that one would be well advised not to cite openly. Accordingly, its title is not mentioned a single time in the Encyclopédie, although quotes from the work itself are found fairly frequently (32 times). In the article "Parlement"-ironically-Jaucourt slyly quoted the work under another title: "mélanges de littérature \&o de philosophie." ${ }_{35}$ Jaucourt wisely avoids the "illegal" title Lettres philosophiques, and refers here to the revised form of the work which appeared in 1739, under the title Mélanges de littérature et de philosophie, as part of volume 4 of the Ledet edition of Voltaire's complete works published in Amsterdam. ${ }^{36}$

As more time went by, and newer battles erased the memory of older skirmishes, there are indications that contributors viewed this book as less likely to raise the hackles of their censors. Indeed, in the four volumes published in or before 1754, quotes from the Lettres philosophiques were either attributed indirectly or not at all; in both cases, Voltaire's name never appeared directly next to the borrowed passage. As far as we can tell, this work was not quoted in the subsequent five volumes, but then it was quoted quite profusely in the remaining volumes (10-17) that appeared en masse

\footnotetext{
34 “. . la cause finale pour laquelle toutes les sociétés ont été formées."

${ }^{35}$ Encyclopédie, 12: 41.

${ }^{36}$ Our thanks to Nicholas Cronk for identifying this edition.
} 
in 1765 . In these instances, $38 \%$ (6 out of 16) of the citations are attributed directly to Voltaire. This change in practice can be interpreted in different ways, but it does seem to suggest first, that this work was no longer deemed to be as subversive as it once was, and second, that Voltaire's power as an authority had grown increasingly strong during this period: the early 1760 s was also the time when Voltaire was undertaking his campaign on behalf of the Calas family, Jean Calas having been executed in 1762 .

\section{A FOLKSONOMY OF SOURCES}

While there does seem to be a loose correlation between publication status and attribution score, this correlation breaks down in a number of cases. Duclos's Considérations sur les mours was only published with a permission tacite, but has a higher attribution score (4.8) than his Histoire de Louis XI (3.75), which was published with royal privilège. Another outlier is Bossuet's Discours sur l'histoire universelle, which in addition to being published with a privilège was a canonical work; yet it only has an attribution score of 4 . When one looks more closely at these citations, the reason why these scores are so low becomes clear: contributors regularly pilfered these texts without any attribution whatsoever. If anyone wanted to brandish the charge of plagiarism, this would be the place.

But on closer analysis, this charge seems inappropriate, or at the very least anachronistic. Indeed, when comparing on a case-by-case basis which of these citations are attributed, it becomes clear that contributors distinguished between different kinds of primary sources. These distinctions may not have been precise, but still reflect a kind of folksonomy, which took the following form: passages that expressed an authoritative judgment or contained a particularly elegant turn of phrase were generally attributed to their author, whereas anecdotes, jokes, historical descriptions, and other "trivial" matters were not. The latter seemed to fall into the common domain, and could be borrowed verbatim, without attribution. In some respects, this practice reflects the humanist habit of extracting noteworthy passages from learned works and transcribing them into commonplace books, for later use-except that these books, whether personal or commercial, often recorded the source, as well. ${ }^{37}$ This encyclopedic practice highlights a further distinction between authoritative and truly commonplace passages. For instance, the only time that a contributor-d'Alembert, no

\footnotetext{
${ }^{37}$ See notably Blair, Too Much to Know, 213-29.
} 
less-did not attribute a quotation from Leibniz's Essais de théodicée in any manner whatsoever, it was when retelling a witticism of Alphonse de Castille: "if God had called him into His council when he created the world, he would have given good advice." ${ }_{38}$ The "authorship" of this quote was arguably not Leibniz's, even though the wording certainly was.

It is this kind of extraction that seems to account for the lower attribution scores of historical works. Duclos's Histoire de Louis XI was often cited without attribution, precisely because contributors savored the anecdotes and details it contained, such as the grisly story about Jacques de Nemours's execution that Boucher d'Argis recounts in "Enfant (jurisprudence)," 39 or the bureaucratic innovation that he transmits verbatim in "Contre-signer." ${ }_{40}$ When he relays a moral judgment made by Duclos in this same Histoire, however, Boucher d'Argis credits the author and title by name. ${ }^{41}$ Only when passing judgment could historians be sure to be elevated to the rank of authors. In a similar vein, contributors regularly mined Bossuet's Discours sur l'histoire universelle for stories and descriptions, but only acknowledged their source half the time. A typical example can be found in the article "Gage," where Jaucourt reproduces, paraphrasing ever so slightly, a lengthy passage concerning Egyptian burial rites. ${ }^{42}$ Interestingly, he does not include a reference to Bossuet, but in another common gesture, discussed below, he does list a series of more scholarly references at the end of the article. By contrast, in the few instances where contributors cited Bossuet's Oraisons funèbres, they provided a precise attribution of author and title.

This folksonomic distinction between authoritative and commonplace passages even applied to the most canonical of works. The one occasion that Montaigne is not credited in any form at all for a passage of the Essais occurs when Jaucourt retells a mythological episode using Montaigne's exact words, but attributes it to a Latin source. ${ }^{43}$ Jaucourt repeats this proc-

38 “.... si Dieu l'eût appellé à son conseil quand il fit le monde, il lui auroit donné de bons avis." "Crystal (cieux de)," Encyclopédie, 4: 527. Compare with the Essais de théodicée, 242.

${ }^{39}$ Encyclopédie, 5: 654. Compare with Charles Duclos, Histoire de Louis XI (Paris: Guerin and Prault, 1745), 135 [FRANTEXT].

40 "Contre-Signer," Encyclopédie, 4: 141. Compare with Histoire de Louis XI, 331.

41 "Exécuteur de la haute justice," Encyclopédie, 6: 232. Compare with the Histoire de Louis XI, 71.

${ }^{42}$ Compare Jaucourt, "Gage," 17: 791, with Bossuet, Discours sur l'histoire universelle (Paris: S. Mabre-Cramoisy, 1681), 447 [FRANTEXT]. This article, a late addition placed out of alphabetical order, should not be confused with the earlier article "Gage" by Boucher d'Argis, found in volume 7.

${ }^{43}$ See "Corne (physiologie)," Encyclopédie, 4: 246. Compare with "De la force de l'imag- 
ess in "Cruauté," an article that includes a passing reference to Montaigne, but that credits Tacitus for an anecdote that is in fact borrowed, without attribution, from the essay "De l'utile et de l'honneste." ${ }_{44}$ Jaucourt refers the reader to "Tacite, liv. III. ch. lj.," but we were unable to locate the source of this anecdote anywhere in the Annals. Jaucourt was not the only contributor to proceed in this fashion. Alexandre Deleyre, in the article "Fanatisme," quotes a speech that Montaigne imagines Aztec messengers addressing to Cortez, as though it were a historical utterance. ${ }^{45}$ Accordingly, he does not attribute it to Montaigne, who is, however, cited elsewhere in the article.

\section{THE WORLDLY STYLE OF CITATION}

There is a final category of unattributed quotations that remains to be discussed, and that explains the less than perfect scores of a Montesquieu, Dubos, or Barbeyrac. In many instances, the encyclopédistes would quote an author they are citing in one place, but then incorporate other, unacknowledged quotes elsewhere in the article. The article "Ridicule" by Jaucourt is typical in this regard: on five occasions, he borrows from Duclos's Considérations sur les mours without any indication that he is citing this, or any, work. Yet then in the final paragraph he quotes Duclos directly. Almost all contributors followed suit, and in most cases did not reference their primary sources each and every time they cited them.

There are a number of reasons why this practice, too, does not deserve to be considered a form of plagiarism. First, in most cases it was openly acknowledged. Articles often concluded with an indication that "This article is excerpted in part from the cited works of these authors" (see "Douleur"), ${ }^{46}$ before providing a list of consulted works. Hence, the article "Manichéisme," which contains sixteen unattributed quotes from Leibniz, merely presents itself as an echo of those "most learned pens of Europe. . . Among whose great number of authors, one can count M. Jaquelot, M. le Clerc, \& M. Leibnitz." ${ }^{47}$ Other articles ended on a more specific note, and

ination," Essais, ed. P. Villey and V.-L. Saulnier (Paris: Presses Universitaires de France, 1978), bk. 1, chap. 21, p. 98.

44 "Cruauté," Encyclopédie, 4: 518. Compare with Essais, bk. 3, chap. 1, p. 803.

45 "Fanatisme," Encyclopédie, 6: 394. Compare with "De la moderation," Essais, bk. 1, chap. 30, p. 201.

46 "Cet article est extrait en partie des ouvrages cités de ces auteurs."

47 “. . . les plus savantes plumes de l'Europe. . . . Parmi ce grand nombre d'auteurs, on peut compter M. Jaquelot, M. le Clerc, \& M. Leibnitz." 
informed the reader that "This article is entirely drawn from M. du Marsais' book of tropes," as in the case of "Metonymie." 48 Articles could also begin with an indication of their source material: the article "Souveraineté," for instance, opens with the statement, "one can define with Pufendorf . ..," and then quotes passages from Barbeyrac's translation. The article "Aristocratie" draws abundantly from The Spirit of the Laws, but notes up front, "As for the laws relative to the aristocracy, one can consult the excellent work of $\mathrm{M}$. de Montesquieu. Here are its main points." ${ }^{49}$ This practice, moreover, was fully endorsed by d'Alembert, who recounts how the humanist and university professor Charles Rollin "took the liberty of inserting into his writings the most beautiful excerpts of ancient and modern Authors in their entirety. He was content to confess, in his prefaces, to this sort of theft, which by the same admission ceased being one, \& of which the public was quite grateful, because his work was useful." $" 50$

As this comment reminds us, the encyclopédistes had a pedagogical objective in mind, as well. Contributors often sought to summarize lengthy, complicated tomes in the space of a few columns. Hence, the article "Manichéisme" draws on passages from Leibniz's Essais de théodicée that span pages 112 to 327 . The article "Etat de nature," which is drawn almost entirely from Locke's Second Treatise, without ever citing it, similarly covers material ranging from $\mathbb{} 4$ all the way to $\$ 128$. Identifying each and every one of these quotations was clearly viewed as tedious and detrimental to the experience of reading the text. Evidence of this outlook can be found in the manner that contributors often referenced authors when they did attribute citations: they would not place the citation in quotation marks, or even clearly delimit where it began and ended, but simply would include the author's name in the text ("comme dit M. de Montesquieu") and then would keep writing. André Morellet found an in-between format for acknowledging citations, as his use of italics in "Fatalité" indicates.

These practices can more generally be placed under the heading of a "worldly style," as they largely stemmed from the fear of appearing pedan-

48 "Cet article est tiré entierement du livre des tropes de M. du Marsais."

49 “. . . on peut la définir avec Puffendorf ....”; “Quant aux lois relatives à l'aristocratie, on peut consulter l'excellent ouvrage de M. de Montesquieu. Voici les principales."

50 “. . . se permettoit d'insérer en entier dans ses ecrits les plus beaux morceaux des Auteurs anciens \& modernes. Il se contentoit d'avertir en général dans ses préfaces, de cette espece de larcin, qui par l'aveu même cessoit d'en être un, \& dont le public lui savoit gré, parce que son travail étoit utile." "Avertissement," Encyclopédie, 3: vii, emphasis added. 
tic. This style was perhaps best defined by Voltaire himself, in the "AvantPropos" to his Essai sur les moeurs (1756). Addressing Emilie du Châtelet, Voltaire observed,

You finally want to overcome the distaste that modern history causes you [...] and to form a general idea of the nations that inhabit and desolate the earth. [. . . The goal of this work is not to ascertain in which year a prince unworthy of being known succeeded a barbarian prince from a rude nation. [. . .] And, in as much as it is necessary to know the great actions of rulers who have rendered their peoples better and happier, it is equally necessary to ignore the run-of-the-mill kings who do nothing but burden the memory. ${ }^{51}$

As a corollary of this rejection of petty facts and chronological suites, Voltaire did not burden his reader with many references or citations, an oversight for which William Robertson later reproached him:

I have not once mentioned M. de Voltaire, who, in his Essay sur l'histoire generale, has reviewed the same period, and treated of all these subjects. This does not proceed from inattention to the works of that extraordinary man, whose genius, no less enterprizing than universal, has attempted almost every different species of literary composition. [. . .] But as he seldom imitates the example of modern historians in citing the authors from whom they derived their information, I could not, with propriety, appeal to his authority in confirmation of any doubtful or unknown fact. ${ }^{52}$

Adopting the same stance as Voltaire, the encyclopédistes rejected by and large the "learned style" that Robertson alludes to here, as their target audi-

\footnotetext{
${ }_{51}$ "Vous voulez enfin surmonter le dégoût que vous cause l'histoire moderne . . . et prendre une idée générale des nations qui habitent, et qui désolent la terre. . . . Le but de ce travail n'est pas de savoir en quelle année un prince indigne d'être connu succéda à un prince barbare chez une nation grossiére. . . . Autant qu'il faut connaître les grandes actions des souverains qui ont rendu leurs peuples meilleurs et plus heureux, autant on peut ignorer le vulgaire des rois qui ne pourrait que charger la mémoire," Essai sur les mœurs et l'esprit des nations, 2 vols., ed. René Pomeau (Paris: Bordas, 1990), 1: 195. See also J. G. A. Pocock, Barbarism and Religion, 5 vols. to date (Cambridge: Cambridge University Press, 2001), 2: 102-3.

${ }^{52}$ Robertson, The History of the Reign of the Emperor Charles V, 2 vols. (Dublin: W. Smith [and 20 others], 1762-71), 1: 305 [ECCO].
} 
ence was not fellow scholars, but rather the educated elite. This privileging of a worldly style further marks the Encyclopédie as an Enlightenment text: if your goal was to "change the common way of thinking," as Diderot claimed, you had to write in a plainer and more accessible style. ${ }^{53}$

There was, however, a counter-current to this attempt to please the common reader. While contributors often hesitated to burden the body of the article with references, they regularly piled them up at the end. Moreover, these lists of sources usually privileged the arcane and erudite over the contemporary and accessible. As we saw with "Gage," Leibniz's Essais de théodicée was not cited, but hefty Latin tomes by Jacques Cujas, Reiner Bachovius, Arnold Vinnius, Christian Thomasius, and others were. No doubt the contributors consulted such erudite works, at least on occasion. But we can also catch them dressing up their references to look more scholarly than they might actually have been. In the article "Interrègne," for instance, Jaucourt cites Barbeyrac's translation of Pufendorf, but refers only to Pufendorf's Latin dissertation on the topic, De interregnis. ${ }^{54}$ He repeats this process in "Etats composés," where he pointedly refers the reader to "la dissertation latine de Puffendorf, de systematibus civitatum, in-4," but is in fact just quoting again from Barbeyrac's translation. ${ }^{55}$

Finally, it is worth pointing out that the encyclopédistes were usually more than happy to cite ancient authorities, and did not seem to think that this kind of reference, most often with attribution got in the way of their worldly readers. Articles that buried references to modern authors often brandished their classical erudition: in "Hospitalite," for instance, Jaucourt references Heliodorus, Homer, Livy, Virgil, and Tacitus, but not Montesquieu, from whom he in fact borrows the passage attributed to Tacitus. ${ }^{56}$ Part of the reason why modern texts were routinely ingested without acknowledgment in the Encyclopédie seems to stem from the pro-ancient bias that characterized so many Enlightenment works. ${ }^{57}$

53 “. . . changer la façon commune de penser," in "Encyclopédie," Encyclopédie, 5: 642.

54 "Interrègne," Encyclopédie, 8: 833. Compare with Barbeyrac, trans., Les devoirs de l'homme, et du citoien, tels qu'ils lui sont prescrits par la loi naturelle (Amsterdam: Henri Schelte, 1707), 304 [MOME].

55 "Etats composés," Encyclopédie, 6: 19. Compare with Barbeyrac, Les devoirs de l'homme, 297-98.

56 "Hospitalité," Encyclopédie, 8: 315. Compare with Montesquieu, De l'esprit des lois, bk. 20, chap. 2. The conclusion to this article, on the esprit de commerce, is also drawn from this source.

${ }^{57}$ On the relationship between the philosophes and the ancients, see Edelstein, The Enlightenment: A Genealogy (Chicago: University of Chicago Press, 2010). 


\section{COMPILING THE ENCYCLOPÉDIE}

While our focus in this article has been on when and why contributors to the Encyclopédie did not cite their sources, the results of the sequence alignment also shed light on the way in which articles were written. Indeed, when we move from an Encyclopédie article to a primary source, and examine the chapter or section heading in which the borrowed passage features, we often notice a striking parallel: many times these headings are identical, or nearly, to the title of the article. Hence, in the articles "Pouvoir" and "Tyrannie," Jaucourt reproduces passages from the chapters "Of Paternal Power" and "Of Tyranny," respectively, in Locke's Second Treatise. For the article "Usurpation," he goes one step further, and copies out the entire chapter "Of Usurpation," again in Locke. The same pattern recurs in the case of the quotations from the abridged version of Locke's Essay Concerning Human Understanding, in French, the Abrégé de l'entendement humain: the article "Proposition" borrows from the chapter "Des propositions frivoles"; the article "Foi," from the chapter "Des bornes distinctes de la Foi \& de la Raison"; the article "Axiome," from the chapter "Des maximes"; and so on and so forth. In these instances, we can almost catch the contributors in the process of researching their articles: to find information on a particular topic, they naturally turned to an authority on the subject, and pored over the table of contents (or index) for a match. It was the early modern precursor to Google.

This kind of regression analysis yields other findings, as well. It strongly suggests the use of commonplace books on the part of the contributors. This hypothesis rests on the fact that fairly unexceptional passages from a primary source sometimes reappear in articles published volumes apart. For instance, the articles "Loi écrite" and "Religion," both most likely authored by Jaucourt, cite the exact same short passage from Bossuet's Discours sur l'histoire universelle: "the time of natural law, when men had nothing more to govern them than natural reason and the traditions of their ancestors." ${ }^{58}$ Assuming that the author of these articles was indeed the same, it is somewhat surprising that at a five-volume distance this exact same quote would reappear, unless, that is, the author had a notation system that allowed him to keep track of such citations.

58 “. . . le temps de la loy de nature, où les hommes n'avoient pour se gouverner que la raison naturelle et les traditions de leurs ancestres." Discours sur l'histoire universelle, 18. Compare with "Loi écrite," 9: 660, and "Religion," 14: 83. 
Finally, we occasionally catch glimpses of the literal composition of the Encyclopédie. There are indeed a number of strange occurrences that can probably best be explained by early modern publication practices. For example, after the end of the article "Coutume," by Samuel Formey, we find a long passage from Montaigne's essay "De la coustume et de ne changer aisément une loy receue"-note again the common presence of "coutume" in both titles. While the passage is placed in quotation marks and attributed, it is not incorporated into the text and seems simply to be sitting there. A likely explanation for this unusual situation may be found in Ann Blair's work on compilation. As she describes it, compilers often copied relevant passages onto slips of paper, which they then arranged into the order of publication..$^{59}$ These collated slips would subsequently be glued onto manuscripts and used to prepare the actual printing. In the case of the Encyclopédie, as opposed to the reference books Blair analyzes, there would generally have been an intermediate stage, namely the integration of these slips into the article text. But it may be that this stage was occasionally incomplete, or missed altogether, and the slip remained tagged onto the article text, producing what we witness with "Coutume." Another possible trace of a compiling slip can be found at the article "Espèce (histoire naturelle)." In lieu of a text, this article simply reproduces a lengthy quotation from Buffon. The quotation is attributed and a precise reference to the cited work is also supplied; but no other context or commentary is provided. The entry simply reads like a note slip that a contributor would have made while reading Buffon's Histoire naturelle.

\section{CONCLUSION: SUBVERSIVE OR “RADICAL”?}

Our objective in this study was to analyze the subtleties and strategies of (non-)citation in the Encyclopédie. Accordingly, we chose to highlight intriguing patterns, illuminating details, revealing practices, and pregnant silences, in an effort to show that the decision to quote or not was complex, and rested on a number of factors: the publication status of the cited work; the disciplinary nature of the content; the authoritativeness of the author; and the stylistic requirements of writing for an enlightened public. While our dataset is very substantial, we did not wish to make arguments that rested primarily on quantitative analysis, since brute numbers, in this case, could be easily misinterpreted.

${ }_{59}$ Blair, Too Much to Know, 210-26. 
At the same time, this study does offer a rare snapshot of the Encyclopédie at a macroscopic level. This snapshot is incomplete, to be sure, and certainly rather fuzzy, but it nonetheless allows us to identify some important shapes and patterns. What stands out in particular is the overwhelming presence of the two standard-bearers of the French Enlightenment, Montesquieu and Voltaire. De l'esprit des lois and the Essai sur les mours, to consider but them, are both quoted over 500 times in the Encyclopédie, putting them on par in terms of word count with some of the dictionaries used in the production of articles. Compared to the dictionaries, moreover, these texts figure in far more significant articles.

This snapshot of the Encyclopédie would thus seem at odds with the notion, advanced by Jonathan Israel, that the work "did [not] reflect the views and perspectives of the leading figures of the French moderate mainstream-Voltaire, Montesquieu, Maupertuis, and Turgot." 60 In Israel's view, these "mainstream" authors were indebted to a "Lockean-Newtonian enterprise," which was absent: "Bacon, Locke, Newton, and Clarke do not in fact figure prominently in the major articles on philosophy, religion, politics, and society." 61 Instead, he argues that the Encyclopédie "was, in essence, a 'Spinosiste' conspiracy or what an anti-philosophic journal in Paris in 1802 called an assemblage of 'scepticism, materialism, and atheism." " 62 He even contrasts the Encyclopédie with the Spirit of the Laws: "It was what l'Esprit des lois was accused of being but was not." 63

While Israel's work should be praised for revivifying interest in the intellectual history of the Enlightenment project-radical or otherwiseover the long eighteenth century, some of his claims concerning the Encyclopédie's role in this process can be unsettled with the data analyzed in our study. Voltaire and Montesquieu may not have personally written many articles, but their words provide the content for a countless number. ${ }^{64}$ Moreover, Voltaire did eventually contribute 45 articles, though most were in volumes Five through Eight; and in Enlightenment Contested, Israel only discusses volumes One through Three. Israel could hardly have chosen a worse example than the Spirit of the Laws to distinguish the Encyclopédie from the "mainstream" Enlightenment, given how mercilessly this text was pilfered by Jaucourt, whom Israel never even mentions. As for Locke, he

\footnotetext{
${ }^{60}$ Israel, Enlightenment Contested, 849-50.

${ }^{61}$ Ibid., 846.

${ }^{62}$ Ibid., 843.

${ }^{63}$ Ibid.

${ }^{64}$ For more information on Voltaire's Encyclopédie articles, see Euvres complètes de Voltaire (Oxford: Voltaire Foundation, 1987), vol. 33.
} 
features so prominently in major articles on philosophy and politics that they often consist of little else than of his own words: see in particular the articles "Etat de nature," "Gouvernement," "Pouvoir," "Prérogative," and "Usurpation". These borrowings are often unattributed, which partially explains why their presence might be missed; but to be missed implies that they were read, and Israel only considers a dozen or so articles to make his case about the Encyclopédie as a whole. ${ }^{65}$

The macroscopic level from which we were able to discern the use, and often abuse, of authors such as Voltaire and Montesquieu in the compositional process of the Encyclopédie speaks to the value of the sort of "distant" reading facilitated by computational approaches to historical texts, ${ }^{66}$ a mode of reading that must, nonetheless, be tempered by the traditional scholarly practices of "close" reading and intensive analysis of source material. For our part, this dialectic between macro- and micro-analysis has allowed us to occupy a more expansive space between the too-particular and the too-general, helping us avoid, for example, distorting the intellectual project of the Encyclopédie on the basis of scant evidence and, more generally, misconstruing what was genuinely subversive about this work in the first place. It was not the fact, to follow Israel, that "several articles while not directly propagating materialist views could be construed to be doing so indirectly," but rather the fact that contributors were smuggling big chunks of contraband books into an officially sanctioned text, and usually getting away with it. ${ }^{67}$ There was more to being subversive than indirectly implying a possibly materialist opinion. Submerged beneath the surface references to learned books and classical authorities, there lurked within the Encyclopédie a much larger mass of unattributed and forbidden citations from works that challenged the political and intellectual limits of Old Regime France.

Stanford University, University of Chicago, and University of Oxford.

\footnotetext{
${ }^{65}$ There are only fifteen articles listed in the index, and no more are discussed in the body of the text. See Israel, Enlightenment Contested, 963.

${ }^{66}$ On "distant reading," see Franco Moretti, Graphs, Maps, Trees: Abstract Models for Literary History (London: Verso, 2005).

${ }^{67}$ Israel, Enlightenment Contested, 848.
} 